\title{
As obrigações solidárias em Direito Romano
}

\author{
Alexandre Augusto de Castro Correia \\ Livre-docente de Direito Romano na Faculdade de \\ Direito da Universidade de São Paulo.
}

Em Roma existem dois tipos de solidariedade: há a obrigação correal e a obrigação "in solidum". Convém tratar separadamente das duas. A obrigaçã̃o correal dos intérpretes e correspondente à solidariedade moderna, chama-se "duo aut plures rei stipulandi credendi" ou "duo aut plures rei promittendi debendi", segundo seja a favor de dois ou mais credores ou contra dois ou mais devedores ${ }^{1}$. Porisso, a correalidade é ativa e passiva. Seu caráter, entretanto, é o mesmo nos dois casos: cada credor pode exigir de cada devedor a totalidade da obrigação. Também, o cumprimento da obrigação por qualquer devedor e o exercício da ação por qualquer credor extinguem a obrigação em relação aos outros credores e devedores.

A obrigação correal cria tantos vínculos quantos forem os sujeitos, mas seu objeto é um só. Donde o efeito ácima indicado.

Inst., 3,16,1 - "Ex hujusmodi obligationibus et stipulationibus solidum singulis debetur et promittentes singuli in solidum tenentur. In utraque tamen obligatione una res vertitur: et vel debitum accipiendo vel alter solvendo omnium perimit obligationem et omnes liberat".

1. A exposição da matéria, em Direito Romano, pode-se encontrar, dentre outros, no tratado clássico de Girard, aqui seguido, "Manuel Elementaire de Droit Romain", 8. ${ }^{a}$ ed., Paris, 1929, p. 786 e segs. Ver também a bibliografia aí indicada. 
Tradução: "Por estas obrigações a cada um dos estipulantes se deve solidàriamente e cada um dos promitentes se responsabiliza solidàriamente. Mas, ambas essas obrigações têm um só objeto; e o credor que receber ou o devedor que pagar o débito extingue a obrigação de todos e a todos libera"

Em razão da unidade de objeto ("una res vertitur"), exigia o Direito Romano em princípio completa identidade de objeto.

D., 45, 2, 9, 1. Papin. - "Sed si quis in deponendo penes duos paciscatur ut ab altero culpa quoque praestaretur, verius est non esse duos reos a quibus impar suscepta est obligatio".

Tradução: "Mas, se alguém depositando junto a dois depositários pactuar a responsabilidade só dum por culpa é mais verdadeiro dizer não serem dois os obrigados solidários, pois cada qual assumiu uma obrigação diferente" Gaio, D., h. t., 15 - (Estipulação dum usufruto em favor de duas pessôas) - "Si id quod ego et Titius stipulamur in singulis personis proprium intelligatur non poterimus duo rei stipulandi constitui: veluti cum usumfructum aut dotis nomine dari stipulemur, idque et Julianus scribit. Idem ait et si Titius et Seius decem aut Stichum qui Titii sit, stipulati fuerint, non videri eos duos rei stipulandi: cum Titio decem tantum Seio Stichus aut decem debeantur. Quae sententia eo pertinet ut quamvis vel huic vel illi decem solverit vel Seio Stichum, nihilominus alteri obligatus manet: sed dicendum est ut si decem altero solverit, ab altero liberatur".

Tradução: "Se entendermos como próprio de cada um o estipulado por mim e Tício, não poderemos ser considerados co-estipulantes solidários: por exemplo, no caso dia estipularmos um usufruto ou um dote: tal é a opinião de Juliano. O mesmo jurista diz: também se Ticio e Seio estipularem dez ou o escravo Stico, pertencente a Seio, não haverá dois estipulantes solidários: pois, a Ticio se devem apenas dez e a Seio dez ou o escravo Stico. A consequên- 
cia desta opinião é a seguinte: embora o devedor pague dez a Ticio ou a Seio ou dê o escravo a Seio, fica não obstante obrigado para com o outro credor. Mas, devemos dizer: si o devedor pagar dez a um dos credores, fica livre perante o outro". Mais tarde, o Direito Romano atenuou êste rigor.

D., h. t., 5, Juliano: "Nemo est qui nesciat alienas operas promitti posse et fidejussorem adhiberi in ea obligatione: et ideo nihil prohibet duos reos stipulandi constitui, vel promittendi: sicuti si ab eodem fabro duo rei stipulandi easdem operas stipulentur: et ex contrario, duo fabri ejusdem peritiae easdem operas promitteres intelliguntur et duo rei promittendi fieri".

Tradução: "Ninguém ignora poderem prometer-se trabalhos de outrem, acrecentando-se fiador à ourigação: porisso, nada impede a constituição de dois co-estipulantes ou co-promitentes: como quando dois co-estipulantes estipulam os mesmos trabalhos do mesmo operário: e, pelo contrário, dois operários de igual perícia podem prometer os mesmos trabalhos, constituindo-se dois co-promitentes". Aliás, o final do texto de Gaio acima citado exprime idèntico pensamento; há, porém, indícios de interpolação; o final pode ser acrescentado.

A obrigação solidária comporta pluralidade de vínculós e assim, cada sujeito é credor ou devedor. Em consequência, a obrigação pode ser pura e simples, para certo ou certos credores ou devedores solidários e condicional ou a termo para os outros. Institutas, 3, 16, "De duobus reis stipulandi et promittendi", 2: "Ex duobus reis promittendi alius pure, alius in diem vel sub condicione obligari potest: nec impedimento erit dies aut conditio, quo minus ab eo, qui pure obligatus est, petatur".

Tradução: "De dois réus promitentes, um pode obrigar-se puramente; o outro, a prazo ou sob condição, nem impedem o prazo ou a condição a cobrança do que se obrigou puramente". Por outro lado, a unidade do objeto faz extender-se a todos os sujeitos, a causa de extinção da obrigação verificada a favor de qualquer dêles. A dificuldade 
consiste em saber se a pluralidade de vínculos acarreta pluralidade de obrigações ou se pelo contrário a unidade da prestação envolve unidade de obrigação. A doutrina mais difundida, baseando-se em alguns textos afirma existir uma só obrigação. Essa doutrina foi criada sobretudo para explicar o efeito extintivo da "litis contestatio"; seu mais notável representante moderno é Windscheid, 2 \& 293.

D., h. t., 3, 1: "Ubi duo rei facti sunt potest vel ab uno corum solidum peti. Hoc est enim duorum reorum ut unusquisque eorum in solidum sit obligatus possitque ab alterutro peti: et partes autem a singulis peti posse nequaquam dubium est: quemadmodum et a reo et fidejussore petere possumus. Utique enim, cum una sit obligatio una et summa est: ut sive unus solvat, omnes liberentur: sive solvatur ab altero, liberatio contingat".

Traduçâo: "Havendo dois devedores solidários pode-se pedir tudo a um dêles. Pois, é da natureza da obrigação dos dois devedores solidários, obrigar-se cada qual pelo todo, podendo-se pedir tudo de qualquer dos dois. E não há dúvida sôbre a possibilidade de pedirmos uma parte a cada devedor; podemos, da mesma forma, pedir parte ao devedor principal e parte ao fiador. Pois, sendo una a obrigação ela é una e inteira: assim, se qualquer dos devedores pagar, todos os demais se exoneram".

D., 2, 14, 9 - Paulo - "Si plures sint, qui eandem actionem habent, unius loco habentur: utputa, plures sunt rei stipulandi, vel plures argentarii, quorum nomina simul facta sunt, unius loco numerabuntur: quia unum debiturm est. etc.".

Tradução: "Sendo vários os credores, com a mesma: ação, consideram-se como uma só pessôa: suponhamos, por exemplo, diversos estipulantes solidários ou diversos banqueiros, cujos créditos se tenham constituído ao mesmo tempo; êles serão contados como um só credor: pois, o débito é único."

Existe, contudo, igual número de textos em sentido contrário: Inst., h. t., 1: "In utraque tamen obligatione 
una res vertitur:". Tradução: "Ambas essas obrigações têm um só objeto."

Ulpiano, D., 46, 1, "De fidejussoribus", 5, in fine: "Si ex altera earum egerit, utramque consumet, videlicet quia natura obligationum duarum, quas haberet, ea esset ut, cum altera earum in judicium deduceretur, altera consumeretur."

Tradução: "Sem đúvida, se o credor agir em razão duma das obrigações, consumará ambas; pois, a natureza das duas obrigações que tinha é de molde a extinguir uma, quando a outra é deduzida em juízo"

Depois, si a obrigação fôsse única, como poderia ser pura e simples para um devedor e condicional para outro? Como subsistiriam os dois vínculos, apesar da unidade de sujeito, em caso de confusão?

Assim, quando o credor herda dum devedor solidário, conserva contra o outro a ação, obrigando-se a deđūuzir parte do crédito apenas, se entre os devedores houver qualquer sociedade (codevedores "socii"). No caso, também, do credor herdar do devedor acessório, êle conserva a ação contra o devedor principal.

D., 46, 1, "De fidejuss.", 71, pr. - Paulo - "Uranius Antoninus pro Julio Pollione et Julio Rufo pecuniam mutuam accipientibus, ita ut duo rei ejusdem debiti fuerint, apud Aurelium Palmam mandator exstitit Julii bona ad fiscum venerunt: similiter et creditori fiscus successerat. Mandator allegabat se liberatum jure confusionis: quia fiscus tam creditori quam debitori successerat. Et quidem, si unus debitor fuisset, non dubitabam, sicut fidejussorem, ita et mandatorem liberatum esse. Quamvis enim judicio convento principali debitore, mandator non liberetur: tamen ubi successit creditor debitori, veluti solutionis jure sublata obligatione, etiam mandator liberatur: vel quia "non potest pro eodem apud eundem quis mandator esse" Sed cum duo rei promittendi sint, et alteri heres exstitit creditor, justa dubitatio est, utrum alter quoque liberatus est, ac si soluta fuisset pecunia, an persona tantum exempta, confusa obligatione. Et puto aditione hereditatis, confusione 
obligationis eximi personam: sed et accessiones ex ejus persona liberari propter illam rationem, quia non possunt pro eodem apud eundem obligati esse: ut quemadmođuñ incipere alias non possunt, ita nec remaneat. Igitur alterum reum ejusdem pecuniae non liberari: et per hoc nec fidejussorem vel mandatorem ejus. Plane quia is mandati judicio eligere potest vel creditorem, competituram ei exceptionem doli mali, si coeperit conveniri. Cum altero autem reo vel insolidum, si non fuerit societas: vel in partem, si socii fuerunt, posse creditorem agere. Quod, si creditor fidejussori heres fuerit, vel fidejussor creditori, puto convenire confusione obligationis non liberari reum".

Tradução: "Urânio Antonino se constituiu mandante junto a Aurelio Palma em favor de Júlio Polião e Júlio Rufo, os quais receberam dinheiro em mútuo de modo a ficarem devedores solidários. Os bens de Júlio couberam ao fisco; o qual sucedeu também ao credor. O mandante alegava estar exonerado em virtude da confusão, pois o fisco sucedera tanto ao credor como ao devedor. Se fôsse um só o devedor, o mandante indubitàvelmente se exoneraria, como o fiador. Pois, embora o mandante não se exonere quando a ação é proposta contra o devedor principal, êle se exonera quando o credor sucede ao devedor, extinguindo-se a obrigação como por pagamento ou pela impossibilidade de ser alguém mandante "em favor duma pessoa e junto a ela mesma". Sendo, porém, dois os devedores solidários, tornando-se o credor herdeiro dum dêles, é duvidoso se também o outro se exonera, como por pagamento, ou se a extinção da obrigação só se verifica em relação ao devedor de quem o credor se tornou herdeiro. Para mim, em consequência da adição da herança só a pessoa do devedor a quem o credor sucedeu, se exonera, pela confusão: mas, também os acessórios dela se exoneram, por não se poderem obrigar pela mesma pessoa e para com ela mesma. Pois, assim como não se podem obrigar nessas condições, não podem também permanecer obrigados. Portanto, o outro devedor solidário não se exonera, como também não se exoneram seu fiador ou mandante. 
Sem dúvida, como êste, na ação de mandato, pode agir mesmo contra o credor, poderá opor a exceção de dolo se a execução começar por êle, mandante. Contra o outro devedor, poderá agir o credor solidàriamente, não havendo sociedade entre os devedores: do contrário, o credor agírá apenas em parte. Se o credor se tornar herdeiro do fiador, ou o fiador do credor, o devedor não me parece exonerar-se pela confusão."

O ef eito extintivo da "litis contestatio" nas obrigações solidárias se explica pela concepção romana da regra "bis de eadem re ne sit actio": era ela aplicada quando se propunha segunda ação com "causa petendi" idêntica, sendo irrelevante a identidade das pessôas ou da ação.

\section{Fontes da solidariedade}

Embora resulte, em certos casos, do direito positivo, a solidariedade depende sobretudo da vontade humana, das medidas tomadas pelos particulares afim de evitar a divisão da obrigação entre as partes e a alteração de seu montante. A solidariedade surgiu nos contratos verbais, estabelecendo-se originàriamente segundo formas sacramentais por nós conhecidas: pela pronúncia de tôdas as interrogações antes duma única resposta, na solidariedade ativa e pela pronúncia de tôdas as respostas depois duma interrogação única, na solidariedade passiva. (Inst., 3, 16, pr.). A prova da origem da solidariedade se encontra não só no emprêgo das expressões "duo rei stipulandi, promittendi", para indicar a correalidade mesmo produzida por contratos de outra espécie, como também na maneira pela qual Marcelo, D., 19, 2, "Locati", 47, desconhece ainda as regras da correalidade em matéria de contratos de bôa fé e nos termos empregados por Papiniano, D., h. t., 9, pr., declarando possível estabelecer-se a solidariedade não só "verbis", mas "et ceteris contractibus".

Eis os textos: 
Papiniano, D., 45, 2, 9, pr. — "Eandem rem apud duos pariter deposui, utriusque fidem insolidum secutus: vel eandem rem duobus similiter commodavi: fiunt duo rei promittendi: quia non tantum verbis stipulationis, sed et caeteris contractibus, veluti emptione, venditione, locatione, conductione, deposito, commodato, testamento, utputa si pluribus heredibus institutis testator dixit, "Titius et Maevius Sempronio decem dato"

Tradução: "Depositei ao mesmo tempo a mesma coisa junto a dois depositários, com a intenção de obter de ambos a responsabilidade solidária: ou então emprestei a mesmá coisa a dois, nas mesmas condições. Êles se tornam dois devedores solidários, pois a solidariedade resulta não só da estipulação, como dos demais contratos, de compra e venda, locação e condução, depósito, comodato, do testamento, como quando instituindo diversos herdeiros, o testador disser: "Ticio e Mevio dêm dez a Semprônio"

Marcelo, D., 19,2, "Locati”, 47 — "Cum apparebit emptorem conductoremve pluribus vendentem vel locantem singulorum insolidum intuitum personam: ita demum ad praestationem partis singuli sunt compellendi si constabit esse omnes solvendo: quamquam fortasse justius sit etiamsi solvendo omnes erunt electionem conveniendi quem velit non auferendam actori, si actiones suas adversus caeteros praestare non recuset".

Tradução: "Se o comprador ou o locatário houverem vendido ou sublocado a diversas pessoas, de modo a parecerem ter querido obrigar pelo todo cada uma das pessoas com as quais contrataram, cada qual será obrigada à prestação parcial se tôdas forem solventes, embora seja talvez mais justo mesmo sendo tôdas solventes, não tirar ao autor o direito de escolher quem deseja acionar, se êle não recusar transferir suas ações contra os outros"

Papiniano, D., 45, 2, 9, pr-citado, p. 204, supra.

Quanto ao modo de constituição da obrigação solidária, o primitivo rigor das formas foi abandonado no direito clássico. A solidariedade legal resulta em Roma dos seguintes casos: 
1. Preponente e preposto-Ambos respondem "in solidum", o segundo em virtude do "jus civile" e o primeiro por fôrça do edito. Ambos se exoneram pela "litis contestatio" estabelecida com qualquer dêles.

D., 14, 1, "De exercit. act.", 5, 1 - Paulo -_ "Item si servus meus navem exercebit et cum magistro ejus contraxero, nihil obstabit quominus adversus magistrum experiar actionem quae mihi vel jure civili vel honorario competit: nam et cuivis alii non obstat hoc edictum quominus cum magistro agere possit: hoc enim edicto non transfertur actio sed adjicitur".

Tradução: "Igualmente, se meu escravo explorar um navio em seu proveito e eu contratar com seu preposto, nada me impede de exercer contra o preposto a ação que me compete pelo direito civil e pelo direito honorário: pois, o edito não impede a qualquer outra pessoa agir contra o preposto, porque êle não transfere a ação mas lhe acrecenta outra".

D., h. t., 1, 17: "Est autem nobis electio utrừm exercitorem an magistrum convenire volumus".

Tradução: "Pois, podemos escolher entre agir contra o preposto ou contra o próprio dono".

2. D., 11, 1, "De interr. in jure", 20, pr. - (Responsabilidade noxal de vários coproprietários) - "Qui servum alienum responderit "suum esse", si noxali judicio conventus sit, dominum liberat.

Aliter atque si quis confessus sit "se occidisse servum", quem alius occidit: vel si quis responderit "se heredem"; nam his casibus non liberatur, qui fecit, vel qui heres est. Nec haec inter se contraria sunt: nam superiore casu ex persona servi duo tenentur, sicut in servo communi dicimus, ubi altero convento, alter quoque liberatur. At is qui confitetur se occidisse, vel vulnerasse, suo nomine tenetur: nec debet impunitum esse delictum ejus qui fecit, propter eum qui respondit: nisi quasi defensor ejus qui admisit, vel heredis, litem subiit hoc genere: tunc enim in factum exceptione data, summovendus est actor: quia ille 
negotiorum gestorum, vel mandati actione recepturus est quod praestitit. Idem est in eo qui mandatu heredis "heredem se esse" respondit, vel cum eum alias defendere vellet".

Tradução: "Quem declarar seu o escravo alheio, exonerará o dono, se fôr condenado numa ação noxal. o mesmo não acontecerá se alguém confessar "ter moriu o escravo", morto por outrem, ou se declarar "herdeiro"; pois, em tais casos, o autor da morte do escravo ou o herdeiro não se exoneram. Não existe aqui contradição: pois, no primeiro caso há dois obrigados, em consequência do ato do escravo, assim como sucede em relação ao escravo comum; aqui, condenado um dos donos, o outro se exonera. Mas, quem confessa ter morto ou ferido, responde em seu próprio nome, e quem cometeu o delito não deve ficar impune devido à declaração de outrem. Salvo se êste tiver a intenção de defender o culpado ou seu herdeiro: pois, nesse caso, se o autor ainda quizesse perseguir o autor do delito, êle seria repelido por uma exceção; com ef eito, quem pagou a condenação tem contra o autor do delito a ação de gestão de negócios ou de mandato, afim de obter o reembolso da quantia paga em razão do delito."

O mesmo se dirá do mandatário do herdeiro, respondendo "ser herdeiro", ou de quem responde com a intenção de defender o herdeiro".

3. Responsabilidade dos banqueiros e comerciantes de escravos perante seus clientes. Os banqueiros ("argentarii") e os comerciantes de escravos ("venaliciarii") formam em Roma sociedades privadas, sujeitas a regras especiais quanto à responsabilidade individual dos sócios perante terceiros.

D., 21, 1, "De aed. ed.", 44, 1 - Paulo — "Proponitur actio ex hoc edicto in eum cujus maxima pars in venditione fuerit: quia plerumque venaliciarii ita societatem coeunt ut quidquid agunt in commune videantur agere: aequum enim aedilibus visum est, vel in unum ex his, cujus major pars aut nulla parte minor esset, aedilitias actiones 
competere: ne cogeretur emptor cum multis litigare: quamvis actio ex empto cum singulis sit pro portione qua socii fuerint: nam id genus hominum ad lucrum potius, vel turpiter faciendum pronius est".

Tradução: "Esste edito dá ação ao comprador contra o comerciante proprietário da maior parte do escravo; pois, os comerciantes de escravos quase sempre se associam de modo a se reputarem fazendo tudo em comum. Ora, pareceu justo aos edis pudessem as ações estabelecidas no edito ser intentadas contra o comerciante dono da maior parte do escravo ou pelo menos duma parte não inf̌erior a nenhuma outra, afim de não ser o comprađ̃or obrigado a perseguir várias pessoas. Isto, apesar da ação do comprador, em consequência do contrato de compra e venda se poder intentar contra cada comerciante, na proporção de sua participação na sociedade: pois, esta espécie de gente é ávida e procura ganhar a qualquer preço e por qualquer meio".

Justiniano, nas Inst., 3, 16, pr. descreve a forma da estipulação na correalidade ativa e passiva:

"Et stipulandi et promittendi duo pluresve rei fieri possunt. Stipulandi ita, si post omnium interrogationem promissor respondeat spondeo, ut puta cum duobus separatim stipulantibus ita promissor respondeat utrique vestrum dare spondeo: nam si prius Titio sponderit, deinde alio interrogante spondeat, alia atque alia erit obligatio nec creduntur duo stipulandi esse. Duo pluresve rei promittendi ita fiunt, "ut interroget stipulator Maevi, quinque aureos dare spondes? Sei eosdem quinque aureos dare spondes?" respondeant singuli separatim "spondeo".

Quanto aó abandono do primitivo rigor da forma acima indicada, Ulp., D., 45, 2, "De duobus reis constituendis", 3, pr. - "In duobus reis promittendi frustra timetur novatio, Nam licet ante prior responderit, posterior etsi ex intervallo accipiatur, consequens est dicere pristinam obligationem durare et sequentem accedere. Et parvi refert, simul 
respondeant, an separatim promittant: cum hoc actum inter eos sit, ut duo rei constituantur, neque ulla novatio fiet".

Tradução: "Não se deve temer exista novação quando são dois os promitentes. Pois, embora o primeiro responda antes e o segundo se obrigue posteriormente é consequente admitir subsista a primeira obrigação, sendo acessória a segunda. E pouco importa respondam os promitentes juntos ou separadamente, quando a intenção de ambos era criar a solidariedade, não se tendo em vista novar".

$\mathrm{Na}$ prática do período clássico, os romanos se utilisam mais duma cláusula encontrada em títulos gregos e latin̄os e à qual já alude Papiniano, D., h. t., 11, pr.: "Reos promittendi vice mutua fidejussores non inutiliter accipi convenit. Reus itaque stipulandi actionem suam dividere si velit (neque enim dividere cogendus est), poterit eundem ut principalem reum, item qui fidejussor pro altero extitit, in partes convenire: non secus ac si duos promittendi reos divisis actionibus conveniret".

Tradução: "Reconhece-se a utilidade de aceitar copromitentes fiadores uns dos outros. Porisso, se o estipulante quizer dividir sua ação (pois, êle não é obrigado a fazê-lo), poderá acionar por partes distintas o mesmo, como principal promitente e como fiador de outro, exatamente como se perseguisse, por ações separadas, dois copromitentes principais" Dessa forma, os devedores correais se constituiam fiadores uns dos outros, com as palavras: "spondemus alterutrum invicem nos obligantes atque fidedicentes", "prometemos reciprocamente nos obrigar e nos constituir fiadores"

Da estipulação, a solidariedade passou aos demais contratos, não só aos de direito estrito como aos de bôa fé e nestes se estabelecia de qualquer forma.

Mutuo - D., 46, 1, "De fidejuss.", 71, pr. - Paulo (Texto citado pp. 201-203) Diocleciano, C, 4, 2, "Si certum", 5 - "Si non singuli insolidum accepta mutua quantitate, vel stipulanti creditori sponte vos obligastis: licet uni numerata sit pecunia, vel intercessionis nomine hanc pro reo 
suscepistis obligationem : frustra veremini, ne ejus pecuniae nomine vos convenire possit, quam alii muluo dedit, si intra praestitutum tempus rei gestae quaestionem detulistis. Ac multo magis inanem timorem gerilis, si pecunia numerata oleum susceptum instrumento sit collatum: cum si reddendi stipulatio nulla subjecta est, habita solemnis contestatio in suo statu remanente eo, quod vere factum intercessit, ex olei accepti scriptura nilhil deberi manifestum est".

Tradução: "Se não tiverdes aceito solidàriamente a soma emprestada, nem vos tiverdes expontâneamente obrigado perante o credor estipulante, nem tiverdes contraído a obrigação como fiador de quem recebeu a soma, temereis em vão possa o credor agir contra vós, afim de cobrar essa soma, emprestada a outrem, se no tempo fixado para tal fim, provardes não terdes recebido a importância. Vosso temor é ainda menos fundado, se em lugar de dinheiro, o título mencionar azeite recebido: pois, não tendo havido estipulação de entregá-lo, se o devedor se queixar a êsse respeito, ficará obrigado pelo dinheiro realmente recebido; mas, é evidente não haver dívida pelo azeite mencionado no título".

C., h. t., 9 - Os mesmos imperadores, a Alexandre "Cum te in Gallia cum Syntropho certum auri pondus, itemque numeratam pecuniam mutuo dedisse, ut Romae solveretur, precibus adseveras: aditus competens judex, si duos reos stipulandi, vel re pro solido tibi quaesitam actionem, sive ab heredibus Syntrophi procuratorem te factum animadverterit: totum debitum, alioqui quod dedisti solum, restitui tibi jubebit".

Tradução: "Asseguras, em tua súplica haveres com Sintrofo, emprestado, na Galia, certa quantidade de ouro e uma soma de dinheiro sob a condição dessa quantidade e dessa soma serem restituídas em Roma. Procura o juiz competente, o qual se julgar sêres credor da totalidade da soma ou da coisa, junto com Sintrofo, ou julgar teres açã̃o pela totalidade da coisa ou ainda julgar teres procuração ‘os herdeiros de Sintrofo, ordenará não só a restituição de 
tudo quanto te é devido como também da totalidade da dívida"

C., h. t., 12 - Os mesmos imperadores a Teofânio "Si in rem communem cum Ione mutuam sumpsisti pecuniam, nec re, nec solemnitate verborum te obligasti in solidum: etsi eam post integra solvisti, de restituenda tibi parte contra lonem experiri, ut debitum poscens, judice cognoscente potes"

Tradução: "Se em negócio comum com Ion recebeste dinheiro em mútuo, sem te obrigares pela totalidade do débito nem de fato nem pela solenidade das palavras, embora depois pagues a totalidade do débito, podes forçar Ion perante o juiz competente, a te reembolsar a parte dêle na dívida integralmente paga por ti"

Contratos de bôa fé - (Solidariedade) - Papiniano, D., h. t., 9, pr. (citado à p. 204).

Certos autores (Demangeat, "Obligations Solidaires", 1858; Hauriou, "Nouvelle Révue Historique", 1882, pp. 219-240) vêm na correalidade a solidariedade das ações de direito estrito enquanto a responsabilidade dos contratos de bôa fé seria "in solidum" Hauriou excluì da correalidade as "condictiones sine causa" em sentido amplo. Tal opinião é porém insustentável: contradiz o texto citado ( $p$. 204) de Papiniano, segundo o qual a correalidade é possível também nos contratos de boa fé e uma constituição declarando extinta a "condictio furtiva" só pelo pagamento e não pela "litis contestatio", no caso de pluralidade -de ladrões:

C., 4, 8, "De condictione furtiva", 1 -- Diocleciano "Praeses provinciae sciens furti quidem actione singulos quosque in solidum teneri, condictionis vero nummorum furtim subtractorum electionem esse, ac tum demum si $a b$ uno satisfactum fuerit, caeteros liberari: jure proferre sententiam curabit"

Tradução: "O presidente da província não o ignora $\mathrm{e}$ declarará na sentença que na ação de furto cada qual responde pelo todo; mas na ação condicional de repetição de 
dinheiro roubado, se ela fôr proposta contra um dos ladrões, os outros só se exoneram na hipótese do primeiro satisfazer por completo o credor".

Ora, um dos efeitos da correalidade, pelo menos no direito clássico, é extinguir a obrigação para todos os devedores, em consequência da "litis contestatio" estabelecida pelo credor com um dêles. Tal não ocorre como se vê pela constituição citada, na "condictio furtiva" Proposta contra um dos responsáveis, esta ação só exonera os demais, se o devedor satisfizer por completo ao credor. Tal é precisamente o efeito das obrigações "in solidum"; porissı, Hauriou abriu em sua doutrina exceção para a "condict ț sine causa" Uma teoria intermediária, proposta por Accarias $\left(2, n .^{\circ} 454\right.$ - citado por Girard, autor seguido nesta exposição) vê na obrigação "in solidum" modalídade de obrigação correal e procura assim evitar a dificuldade oposta pelos dois textos citados, os quais tratam de obrigação "in solidum" originária de falta comum e não de convenção. A êste ponto voltaremos ao tratarmos das fontes das obrigações "in solidum"

A solidariedade se podia estabelecer por pacto de constituto - Ulpiano, D., 13, 5, “De pec. const.", 16, pr. - "Si duo quasi duo rei, constituerimus, vel cum altero agi poterit in solidum"

Tradução: "Se duas pessoas se obrigarem por constituto, como devedoras solidárias, cada uma poderá ser acionada pela totalidade do débito".

Também num testamento, contendo legado, a solidariedade podia figurar, passivamente, a cargo dos herdeiros ou ativamente em proveito dos legatários. Sôbre a correalidade passiva temos o texto já citado de Papiniano, D., $45,2,9$, pr.; sôbre a correalidade ativa, Paulo, D., 31, "De leg.", II, 16 - "Si Titio aut Seio, "utri heres vellet", legatum relictum est: heres alteri dando, ab utroque liberatur. Si neutri dat, uterque perinde petere potest, atque si ipsi soli legatum foret: nam ut stipulando duo rei constitui possunt, ita et testamento potest fieri" 
Tradução: "Se um testador deixar legado a Ticio ou a Seio, a cargo do herdeiro, o qual poderá escolher o legatário, o herdeiro pagando a um exonera-se perante os dois. Se não pagar a nenhum dêles, ambos podem exigir o legado, como se fôsse feito a um só: pois, assim como pela estipulação um devedor pode ter dois credores solidários, assim também um herdeiro pode ficar obrigado, por testamento, a dois legatários, pela mesma soma".

Quais as razões de inserção da cláusula de solidariedade ou correalidade nos atos jurídicos, pergunta Girard? E responde: eram as mesmas pelas quais as partes podiam considerar vantajoso afastar a divisão, permitindo ao credor exigir tudo de cada devedor, aos credores agir pela totalidade do crédito contra o devedor.

A correalidade passiva tornará possível, a quem vende a vários compradores, ou empresta dinheiro a vários mutuários, reclamar o pagamento por inteiro a um só dos devedores, sem ficar obrigado a propôr tantos processos quantos forem os devedores nem sujeitar-se ao prejuizo resultante da insolvência de qualquer dêles.

Servirá também para realisar a fiança, quando o mutuante ou o vendedor não se contentam com o só compromisso do mutuário ou comprador, declarando vender ou emprestar sòmente se com estas últimas pessoas se obrigar solidàriamente também outra, por contrato verbal.

A correalidade ativa aparecia quando diversas pessoas, contratando no interêsse comum, queriam dar a uma delas, presente na época do vencimento da obrigaçẩo, o direito de exigir pagamento integral, sem para isso necessitar de mandato judicial, mesmo quando no processo das "Ações da Lei", não se conhecia ainda o mandato judicial. Outro caso de correalidade ativa é o da pessoa, contratante única, colocando a seu lado um homem de confiança, o qual, sem mandato judicial, antes mesmo de sua introdução, podia agir contra o devedor para efetuar a cobrança. Finalmente, a correalidade era estabelecida pelo testador, legando certa soma a duas pessoas, com a condição de ser a soma 
atribuída a quem a reclamasse primeiro; podia tainbém o banqueiro abrir um crédito a dois clientes, concedendo-o porém a quem primeiro se utilizasse dêle.

II. Efeitos da correalidade - Na solidariedade passiva ou ativa, a correalidade suscita duas questões modernamente chamadas da obrigação e da contribuição. Quais os direitos do credor único contra cada devedor correal, dos diversos credores correais contra o devedor único? Vem depois a questão da prestação de contas entre credores na solidariedade ativa e entre devedores, na solidariedade passiva.

Quanto à obrigação, as regras aplicáveis são idênticas, na solidariedade ativa como na passiva.

$\mathrm{Na}$ correalidade passiva o credor tem contra cada devedor os mesmos direitos que teria contra um devedor único; exercendo-os, porém, contra um êle os consuma contra todos. Pode o credor exigir de cada devedor pagamento total, exonerando a todos os outros devedores. O mesmo efeito liberatório resulta da aceptilação ou da novação, feitas a ou com um devedor.

Pagamento: Inst., 3, 16, 1 - (texto citado, p. 197).

Aceptilação: D., 45, 2, 2 - Javoleno - "Cum duo eandem pecuniam aut promiserint aut stipulati sunt, ipso jure et singuli insolidum debentur et singuli debent. Ideoque petitione, acceptilatione unius tota solvitur obligatio".

Tradução: "Quando duas pessoas prometem ou estipulam a mesma soma, cada uma delas é de pleno direito devedora e credora solidária. Porisso a obrigação se extingue em sua totalidade, pelo pedido e pela aceptilação duma só".

Novação: D., 16, 1, “Ad Sc. Vell”, 20 - Africano "Si pro uno reo intercessit mulier, adversus utrumque restituitur actio creditori".

Tradução: "Se u'a mulher se obrigou por um de dois devedores solidários, o credor é restabelecido em sua ação contra ambos". Igualmente ainda, o credor exonera a todos os devedores em consequência da "litis contestatio" celebrada com um, salvo se dividir entre os devedores o pe- 
dido, como pode fazer, querendo, afim de proporcionar a pretensão aos recursos de cada um.

Ulpiano, D. 46, 1, “De fidejuss.", 5, in fine. (Citado, p. 201). O juramento necessário, deferido a um devedor e por êle prestado, exonera os outros devedores. Ulpiano, D., 12,2, "De jurejur.", 28, 3.

"Ex duobus reis promittendi ejusdem pecuniae alter juravit: alteri quoque prodesse debebit".

Tradução: "Se um dos dois devedores solidários da mesma soma jurou nada dever, o outro se exonera".

A extinção pela "litis contestatio", foi abolida por Justiniano, o qual invocando a prática anterior, suprimiu a função extintiva da "litis contestatio" chegando mesmo a reconhecer, nas Novelas, ao devedor correal, executado, a faculdade de pedir a divisão entre êle e os outros devedores presentes e em condições de pagar.

C., 8, 40, (41), "De fidejuss.", 28, 2 - O imperador Justiniano a João, prefeito do pretório - "Generaliter sancimus, quemadomodum in mandatoribus statutum est, ut contestatione contra unum ex his facta, alter non liberetur: ita et in fidejussoribus observari. Invenimus etenim et in fidejussorum cautionibus plerumque ex pacto hujusmodi causae esse prospectum. Et ideo generali lege sancimus, nullo modo electione unius ex fidejussoribus, vel ipsius rei alterum liberari; vel ipsum reum fidejussoribus, vel uno ex iis electo, liberationem mereri, nisi satisfiat creditori: sed manere jus integrum, donec in solidum ei pecuniae persolvantur, vel alio modo satis ei fiat. Idemque in duobus reis promittendi constituimus, ex unius rei electione praejudicium creditori adversus alium fieri non concedentes: sed remanere et ipsi creditori actiones integras et personales et hypothecarias, donec per omnia ei satisfiat. Si enim pactis conventis hoc fieri conceditur, et in usu quotidiano semper hoc versari aspicimus: quare non ipsa legis auctoritate hoc permittatur, ut nec simplicitas suscipientium contractus ex quacumque causa possit jus creditoris mutilare" (ano 531). 
Tradução: "Ordenamos que a disposição por nós decretada sôbre os mandantes, pela qual a execução diriğida contra um não exonera o outro, seja também observada em relação aos fiadores. Pois, sabemos da existència de pactos a êsse respeito, mesmo nas fianças. Porisso ordenamos, mediante esta lei geral, que de nenhum modo a escolha dum dentre os fiadores ou do próprio devedor exonere os outros fiadores ou o devedor, salvo se o escolhido pelo credor houver pago. Queremos, pelo contrário, conserve o credor, apesar da escolha, a integridade de seu direito contra os outros, até ser completamente pago ou de outra forma satisfeito. O mesmo dispomos sôbre dois devedores correais: embora escolha especialmente um, o credor conserva todos os direitos contra o outro, as ações, tanto pessoais como hipotecárias, até satisfação plena. Se isto acontece diàriamente, por fôrça de convenções, porque não o permitir pela autoridade da própria lei, para a inadvertência dos credores não os privar dêsse privilégio, em virtude de não o terem reservado para si expressamente?." (531).

Éste regime suscita a questão de saber se a coisa julgada a favor dum devedor solidário pode ser invocada pelos outros, assim como a coisa julgada em favor do devedor principal pode ser invocada pelo fiador, de acôrdo com um tex to interpolado do D., 12, 2, "De jurejur.", 42, 3 - Pompônio, no livro 18 das "Cartas" — "Item si reus juravit fidejussor tutus sit: quia et res judicata secundum alterutrum eorum, utrique proficeret"

Tradução: "Se o principal obrigado jurou, o fiador se exonera, pois a decisão pronunciada em favor de um deve servir a ambos".

Quanto à faculdade do devedor correal executado pedir a divisão, Novella 99 -- Comentando as palavras de Justiniano sôbre fiança recíproca, pensa Cuq (segundo citação de Girard, op. cit., p. 790, n. 4) tratar-se não de verdadeira fiança mas de expediente destinado a obter pagamento rápido no caso de ausência ou morte dum dos devedores. 
A Novella 99 cuida dos devedores solidários ("De reis promitendi"). Se o credor tiver diversos devedores, fiadores uns dos outros, ("alterna fidejussione") sem a cláusula de solidariedade, todos os devedores responderão igualmente ("ex aequo"). Havendo cláusula de solidariedade, deverá ser observada; entretanto, cada devedor não ficará desde o início obrigado pela totalidade do débito, respondendo apenas pela parte assumida ("sed interim secundum partem qua unusquisque obligatus est"). A ação se proporá contra todos os devedores presentes e em condições de pagar, se assim entender o credor.

Os devedores solventes e presentes cumprirão, cada um de acôrdo com sua parte, a obrigação contraída sob promessa de fiança recíproca ("sub alterna promissione") $e$ em razão da qual se obrigaram pelo todo. Assim, a divida comum não se tornará dívida própria de cada um.

Em caso de insolvência total ou parcial de todos ou alguns dos coobrigados ou no de ausência dos mesmos, cada coobrigado, além do acionado deverá pagar tudo quanto o credor não poude receber dos outros. Assim, o credor conservará integralmente a obrigação, nenhum dano sofrendo, embora os coobrigados tenham combinado algo à sua revelia. Cada devedor, por sua vez, responderá pela parte da obrigacãa assumida por ocasião do ato, sem poder por dolo ou quaisquer artifícios, contrariar as disposições da novela. Achando-se presentes todos os coobrigados, deverá o juiz da causa chamá-los examinando a questão em seu todo e proferindo sentença comum a todos. Todos os coobrigados serão assim adstritos ao cumprimento da obrigação; sua situação financeira será examinada e a divida liquidada segundo a lei e a justiça"

As mais difíceis controvérsias se travam a respeito dêste texto. Já citamos uma opinião de Cuq, referida por Girard, autor do qual, repetimos, é extraída tôda a presente exposição.

Os autores procuram restringir o alcance da reforma de Justiniano, visivelmente contrária ao espirito da solidariedade. Esta reforma, porém, é absolutamente geral. 
Alguns encontram restrição na referência do texto sôbre a caução prestada pelos codevedores uns aos outros. Tal restrição é porém aparente, pois, no periodo post-clássico, a fórmula "spondemus alterutrum invicem nos obligantes atque fidedicentes", (Pap., D., 45, 2, 11, pr.-p. 208) é o meio habitual de estabelecer a solidariedade nos atos jurídicos. Entretanto, baseando-se nessa terminologia, certos autores como Ferrini ("Pandette", pp. 560-61, citado por Girărd) sustentaram que a inovação de Justiniano só se aplicaria aos fiadores recíprocos e não aos devedores solidários. Collinet, por sua vez, pretende aplicar o texto de Justiniano ùnicamente às cauçôes simples e não às solidárias.

Depois da "litis contestatio", e com maior razão, a obrigação solidária ou correal se extingue pela perda da coisa, verificada sem culpa nem mora de qualquer devedor. Há, pelo contrário dúvidas no caso contrário, motivadas por conflito de textos, um de Pompônio e outro de Marciano. Ei-los, com as respectivas traduções: Pompônio, D., 45, 2, 18 - "Ex duobus reis ejusdem Stichi promittendi factis, alterius factum alteri quoque nocet".

Tradução: "Sendo dois os devedores solidários do mesmo escravo Stico, o fato de um prejudica ao outro".

Marciano, D., 22, "De usuris", 32, 4 - "Sed si duō rei promittendi sint, alterius mora alteri non nocet".

Tradução: "Mas, se forem dois os devedores solidários, a mora de um não prejudica ao outro".

Sôbre a mora, encontramos ainda o texto de Paulo, D., 50,17, 172, 2: "Unicuique sua mora nocet: quod et in duobus reis promittendi observatur".

Tradução: "O devedor em mora responde pelos danos causados e esta regra se observa também em relação aos devedores solidários".

Diversas teorias procuram explicar a divergência dos textos, em matéria de culpa e mora: assim, uma delas acrecenta a negação ao texto de Pompônio. outra declara-o interpolado, devido à inovação de Justiniano em matéria de prescrição, outra finalmente supõe tratar-se de controvérsia entre jurisconsultos. 
O Código Civil Francês no artigo 1205 apresenta solução baseada na distinção entre o valor da coisa e as perdas e danos, distinção criada por Pothier e desconhecida dos Romanos.

A obrigação solidária se extingue de modo relativo nos seguintes casos: "capitis deminutio" dum dos devedores, "pactum de non petendo" celebrado com um só devedor, confusão entre o patrimônio do credor e o dum dos devedores, crédito oponível em compensação por um dos devedores. Quanto à prescrição, interrompida contra um dos devedores, interrompe-se também contra os outros, sob Justiniano. Eis os textos:

"Capitis deminutio": D., 45, 2, 19, Pomp. - "Cum duo eandem pecuniam debent, si unus capitis diminutione exemptus est obligatione, alter non liberatur. Multum enim interest, utrum res ipsa solvatur, an persona liberetur. Cum persona liberatur manente obligatione, alter durat obligatus. Et ideo si aqua et igni interdictum est, alicujus fidejussor postea ab eo datus tenetur".

Tradução: "Sendo dois os devedores solidários da mesma soma, se um se eximir da obrigação por mudança de estado, nem porisso se eximirá o outro. Pois, é granue a diferença entre o pagamento da coisa e a liberação da pessoa. Quando esta se exonera, subsistindo, porém, a obrigação, o outro devedor continua obrigado. Porisso, se um devedor sofre a interdição da água e do fogo, o fiador depois dado pelo outro se obriga"

Pacto "de non petendo" - O pacto feito com um dos devedores aproveita aos outros, se houver sociedade entre êles.

D., 2, 14, "De pactis", 21, 5 - Paulo - "In his qui ejusdem pecuniae exactionem habent in solidum, vel qui ejusdem pecuniae debitores sunt, quatenus alii quoque prosit, vel noceat pacti exceptio, quaeritur: et, in rem pacta omnibus prosunt, quorum obligationem dissolutam esse, ejus qui paciscebatur, interfuit: itaque debitoris conventio fidejussoribus proficiet" 
Tradução: "Pergunta-se até que ponto aproveita ou prejudica a exceção do pacto, nos casos de credores ou devedores solidários da mesma soma: e nos pactos reais, ficam exonerados todos quantos foram visados pelo autor do pacto: porisso, o pacto feito com o devedor, aproveifa aos fiadores".

D., h. t., 25, pr. - Paulo - "Idem in duobus reis pre mittendi, et duobus argentariis sociis".

Tradução: "A solução é idêntica, no caso de dois devedores solidários e de dois banqueiros sócios"

O pacto do devedor principal, aproveita ao fiador: Paulo, D., h. t., 21, 5. (citado p. 218). Mas, o pacto do fiador não aproveita ao devedor principal nem aos outros fiadores. Paulo, D., h. t., 23 - "Fidejussoris autem conventio nihil proderit reo: quia nihil ejus interest a debitore pecuniam non peti: imo nec confidejussoribus proderit: neque enim, quoquo modo cujusque interest, cum alio conventio facta prodest; sed tunc demum, cum per eum, cui exceptio datur, principaliter ei, qui pactus est, proficiat: sicut in reo promittendi, et his, qui pro eo obligati sunt"

Tradução: "O pacto do fiador não aproveita ao devedor principal, pois aquêle nenhum interêsse tem na liberação dêste; o pacto nem mesmo aos co-fiadores aproveita, pois, para o pacto feito com outrém ser útil a terceiro, não basta, por parte de quem o faz um interêsse qualquer na liberação do terceiro; é preciso êle ser principal obrigado, em relação àquele a quem se dá a exceção, como acontece no caso do devedor em relação a seus fiadores."

Aliás, se as partes assim o quizerem, podem fazer a remissão aproveitar mesmo ao terceiro, cuja exoneração não interessa ao pactuante; podem extender o pacto do fiador ao devedor principal. Êste não terá a "exceptio pacti", mas a "exceptio doli", à semelhança do pacto do mandatário.

D., h. t., 25, 2 - Paulo — "Sed quamvis fidejussoris pactum reo non prosit, plerumque tamen doli exceptionem reo profuturam Julianus scribit" 
Tradução: "Embora o pacto do fiador não aproveite ao principal obrigado, êle em muitos casos lhe dá, escreve Juliano, a exceção de dolo".

D., h. t., 10, 2 - Ulpiano - "Plerumque solemus dicere, "doli exceptionem subsidium esse pacti exceptionis": quosdam denique, qui exceptione pacti uti non possunt, doli exceptione usuros, et Julianus scribit et alii plerique consentiunt: utputa, si procurator meus paciscatur, exceptio doli mihi proderit, ut Trebatio videtur; qui putat sicuti pactum procuratoris mihi nocet, ita et prodesse".

Tradução: "Dizemos comumente: "a exceção de dolo é subsidiária da exceção do pacto": pois, os que não podem usar da exceção do pacto podem se servir da exceçẩo de dolo; é a opinião de Juliano e de vários outros. Por exemplo, se meu procurador fizer um pacto, caber-me-á a exceção de dolo, como parece a Trebácio, para quem o pacto de meu procurador deve me aproveitar assim como pode me prejudicar".

Confusão: - A confusão entre o credor e um dos devedores, distingue-se, quase sempre, dos efeitos do pagamento: assim, o credor de dois devedores principais, se herdar dum dêles, conservará sua ação contra o outro, ficando eventualmente obrigado a fazer dedução do recebido por herança ao primeiro devedor, se entre os devedores houver convenção pondo em comum entre êles o encargo final da dívida: co-devedores "socii". Também, quando o credor, com um devedor principal e outro acessório herda dêste último, conserva ação contra aquêle.

D., 46, 1, “De fidejuss.”, 71, pr. - (Cit., p. 208). Se tivesse havido pagamento por um dos devedores principais ou pelo fiador, a obrigação se extinguiria, podendo haver apenas recurso por meio de ação distinta. Afastamo-nos ainda mais dos efeitos do pagamento no caso de confusão entre os codovedores. Sendo as dívidas desiguais, a mais fraca é absorvida pela mais forte: assim, a dívida do fiador é absorvida pela do devedor principal. Excepcionalmente, dá-se o contrário quando a caução é superior à divida, quando a obrigação principal é natural: D., 46, 3, “De 
solut.", 95, 3 - Papiniano - "Quod vulgo jactatur, "fidejussorem qui debitori heres extitit, ex causa fidejussionis liberari": totiens verum est, quotiens rei plenior promittendi obligatio invenitur. Nam, si reus duntaxat fuit obligatus, fidejussor liberabitur. E contrario, non potest dici non tolli fidejussoris obligationem, si debitor propriam et personalem habuit defensionem: nam si minori vigintiquinque annis bonae fidei pecuniam credidit, isque nummos acceptos perdidit, et intra tempora in integrum restitutionis decessit herede fidejussore: difficile est dicere causam juris accessit sine contemplatione juris praetorii. Auxilium jussoris obligationem quae principalis fuit, et cui fidejussoris accesit sine contemplatione juris praetorii. Auxilium igitur restitutionis fidejussori qui adolescenti heres extitit, intra constitutum tempus salvum erit".

Traduçâo: "O axioma vulgar: "o fiador, tornando-se herdeiro do devedor principal se exonera da fiança" é verdadeiro quando a obrigação do devedor principal é mais forte. Pois, se o devedor principal se obrigou simplesmente, o fiador se exonerará. Deve-se, pelo contrário, admitir a extinção da obrigação do fiador, se o devedor teve meios de defesa própria e pessoal: pois, se se emprestou de boa fé dinheiro a um menor de vinte e cinco anos, e êste o perdeu, morrendo quando podia pedir a restituição por inteiro e deixando como herdeiro o fiador, é difícil dizer que o direito de restituição, ao alcance do menor, conserva a obrigação fidejussória. $O$ direito de restituição é principal, tendo por acessória a obrigação do fiador, sem de modo algum visar o direito pretoriano. Porisso, o auxílio da restituição se dará, dentro do prazo legítimo ao fiador, tornado herdeiro do menor." tem :

Quando, porém, forem iguais, ambas as dívidas subsis-

D., 46, 1, "De fidejuss,", 21, 1 - Africano - "Non est novum ut fidejussor duabus obligationibus ejusdem pecuniae nomine teneatur: nam si in diem acceptus, mox pure accipiatur, ex utraque obligatur: et si fidejussor confidejussori heres extiterit, idem erit". 
Tradução: “Não é novidade um fiador se obrigar duas vêzes em razão da mesma soma: pois, obrigando-se primeiro a partir de certo dia e depois pura e simplesmente, fica preso por ambas as obrigações; o mesmo acontecerá se um fiador se tornar herdeiro de seu co-fiador"

Compensação - $\mathrm{O}$ devedor pode opor em compensação seu crédito pessoal contra o credor, mas só lhe pode opor o de seu co-devedor se ambos forem "socii" - D., h. t., 10 - Pápiniano - "Si duo rei promittendi socii non sint, non proderit alteri quod stipulator alteri reo pecuniam debet"

Tradução: "Se dois copromitentes não forem sócios, não aproveitará a um dêles o fato do estipulante dever dinheiro ao outro".

Quanto à prescrição, interrompida contra um devedor, interrompe-se contra todos, segundo disposição expressa de Justiniano, C., 8, 3 (40), "De duobus reis", 4, (5).

"Cum quidam rei stipulandi certos habebant reos promittendi, vel unus forte creditor. duos vel plures debitores habebat, vel e contrario multi creditores unum debitorem, et alii ex reis promittendi ad certos creditores debitum agnoverunt, vel per solutionem, vel per alios modos, quos in anterioribus sanctionibus interruptionis invenimus posifos; et nos ampliavimus, vel forte ad unum creditorem quiäam ex debitoribus devotionem suam ostenderunt: vel cum plures essent creditores, debitor, qui solus existeret, ad unum ex his vel quosdam debitum agnovit: et quaerebatur si eis vel ei daretur licentia adversus alios indevotionem suam exercere, et quasi tempore emenso exactionem recusare, vel quibusdam ex debitoribus debitum agnoscentibus, vel in judicio pulsatis, deberent et alii ab omni contradictione repelli: nobis pietate suggerente videtur esse humanum, semel in uno eodemque contractu qualicumque interruptione vel agnitione adhibita, omnes simul compelli ad persolvendum debitum, sive plures sint rei, sive unus: sive plures sint creditores, sive non amplius quam unus. Sancimusque in omnibus casibus, quos noster sermo complexus est, aliorum devotionem, vel agnitionem, vel ex libello admonitio- 
nem aliis debitoribus praejudicare, et aliis prodesse creditoribus. Sit itaque generalis devotio, e nemini liceat alienam indevotionem sequi: cum ex una stirpe unoque fonte unus effluxit contractus, vel debiti causa ex eadem actione apparuit"

Tradução: "Diversos credores solidários têm diversos devedores solidários, ou um credor tem dois ou mais devedores solidários ou pelo contrário diversos credores tem o mesmo devedor solidário; alguns dentre os devedores reconhecem a dívida, perante alguns credores, pagando, ou por qualquer outro modo, considerado pelas leis existentes e que confirmamos, capaz de interromper a prescrição. ${ }^{-} \mathrm{Ou}$ então, alguns devedores reconhecem a dívida perante $o$ credor comum; ou finalmente, o único devedor a reconhece perante um só ou apenas perante alguns credores. Discutia-se, a respeito dêsses casos, se seria permitido, ao devedor ou aos devedores, que tivessem pago a dívida comum, perseguir os outros, pela parte a êles cabível, sem poderem tais devedores opor aos primeíros a prescrição; ou se tendo alguns devedores reconhecido o débito ou sido chamados a juizo, deviam os outros ser privados de qualquer defesa, fundada em falta de reconhecimento ou de citação. Para nós, de acôrdo com a equidade, interrompida a prescrição em relação a um ou a alguns dos obrigados pelo mesmo contrato, interrompe-se em relação aos demais, tanto no caso dum só ou vários devedores, como no dum só ou vários credores. Ordenamos, pois: em todos os casos àcima, interrompe-se a prescrição contra todos os devedores, quando ela se tiver interrompido expressamente contra um ou alguns dêles, seja por pagamento, reconhecimento ou enfim por execução em juízo. Sejam de modo geral todos os devedores obrigados a pagar, afim da injustiça dalguns não servir aos outros de pretexto para se arrependerem de haver cumprido suas obrigações: pois o contrato nasceu da mesma raiz e fonte e a causa do débito surgiu da mesma ação" (531).

Quanto à correalidade ativa, cada credor correal tem s⿳亠ेbre o crédito direitos tão extensos como se fôsse credor 
único; fica apenas sujeito a ver o exercício dêsses direitos limitado pelos direitos iguais de seus co-credores. Cada credor pode exigir pagamento integral ao devedor, e êste é obrigado a pagar ao credor mais diligente, sem direito de reclamar o concurso dos outros; nenhum interêsse tem para êle tal concurso, pois, o pagamento feito a um credor exonera o devedor perante todos. Pode ainda cada credor exonerar o devedor por aceptilação, novação (apesar de aparente dificuldade de textos) e por "litis contestatio". Não é certo tenha sido aqui abolido o efeito extintivo da "litis contestatio", pois a constituição de Justiniano só fala de pluralidade de devedores. A questão é todavía controvertida.

Sôbre a novação, D., 46, 2, "De nov.", 31, 1 - Venuleio — "Si duo rei stipulandi sint, an alter jus novandi habeat, quaeritur: et quid juris unus quisque sibi adquisierit? $\vec{F}$ ere autem convenit, et uni recte solvi, et unum judicium petentem, totam rem in litem deducere. Item unius acceptilatione perimi utriusque obligationem. Ex quibus colligitur unumquemque perinde sibi adquisisse, ac si solus stipulatus esset: excepto eo, quod etiam facto ejus cum quo commune jus stipulantis est, amittere debitorem potest. Secundum quae si unus ab aliquo stipuletur, novatione quoque liberare eum an altero poterit, cum id specialiter agit. Eo magis cum eam stipulationem similem esse solutioni existimemus. Alioquin quid dicemus, si unus delegaverit creditori suo communem debitorem, isque ab eo stipulatus fuerit? aut mulier fundum jusserit doti promittere viro, vel nuptura ipsi, doti eum promiserit? Nam debitor ab utroque liberabitur".

Tradução: "Havendo dois co-estipulantes, pergunta-se se um dêles tem o direito de novar e qual o direito adquirido por cada um? Admite-se, em geral, o pagamento válido a um só, e a dedução integral em juízo, pela propositura da ação por um só. Igualmente, tôda a obrigação se extingue, pela aceptilação dum só. Donde se conclui que um e outro adquirem como se tivessem estipulado sòzinhos. Há, contudo, exceção: cada estipulante, pode perder o de- 
vedor por fato do co-estipulante. Por conseguinte, se um dos co-estipulantes estipula de terceiro, poderá, pela novação, liberar êsse terceiro do co-estipulante, quando agir com tal intenção especial. Sôbretudo por tal estipulação nos parecer semelhante ao pagamento. Do contrário, que diremos, se um dos dois delegar o devedor comum ao seu credor e êste estipular dêle, devedor, ou se a mulher ordenar seja prometido um fundo como dote ao marido, ou devendo casar-se com alguém prometer-lhe êsse fundo, a título de dote? Pois, o devedor se exonera perante ambos".

$\mathrm{O}$ devedor se exonera, também, perante todos pelo juramento, prestado com autorização dum dos credores ou pelo pacto de constituto com um dêles celebrado.

Textos: Paulo, D., 12, 2, "De jurejur.”, 28, pr. - “In duobus reis stipulandi, ab altero delatum jusjurandum etiam alteri nocebit".

Tradução: "Quando dois credores são solidários, o juramento deferido ao devedor por um dêles, prejudica ao outro".

Sôbre o pacto de constituto, Paulo, D., 13, 5, “De pec. const.", 10 - “Idem est, et si duobus reis stipulandi post alteri constitutum, alteri posteà solutum est: quia loco ejus cui jam solutum est, haberi debet is cui constituitur".

Tradução: "O mesmo acontece se um devedor de dois credores solidários, depois de se haver obrigado por constituto a pagar a um dêles, pagar ao outro. Pois, presume-se ter o devedor pago ao credor perante o qual se obrigou por constituto".

A dificuldade relativa à novação provém dum texto de Paulo, D., 2, 14, "De pactis", 27, pr. onde êste jurista, contrariando Venuleio, nega ao credor correal o direito de novar. Tal solução, porém, contradiz o que o próprio Paulo admite em matéria de constituto.

D., 2, 14, “De pactis", 27, pr. - "Si unus ex argentariis sociis cum debitore pactus sit; an etiam alteri noceat exceptio? Neratius, Atilicinus, Proculus, nec si in rem pactus sit, alteri nocere: tantum enim constitutum, ut solidum al- 
ter petere possit. Idem Labeo: nam nec novare alium posse, quamvis ei recte solvatur. Sic enim et his, qui in nostra potestate sunt, recte solvi, quod crediderint licet novare non possint: quod est verum. Idemque in duobus reis stipulandi dicendum est"

Tradução: "Se um de dois banqueiros sócios exonerou o devedor comum, poderá o outro propôr sua ação, sem temer a exceção? Para Neracio, Atilicino e Próculo a convenção, mesmo sendo real, não prejudica ao outro banqueiro. Pois, as constituições dizem apenas que um dêles poderá exigir tôda a dívida. O mesmo pensa Labeão, pois, embora um dos dois tenha cápacidade para receber pagamento, não pode entretanto novar. Assim, pode-se pagar às pessoas em nosso poder, o por elas emprestado, embora não possam elas novar; e, esta opinião é verdadeira. Dirse-á o mesmo de dois credores solidários".

Quanto ao ef eito extintivo da "litis contestatio" não é certo ter sido êle aqui abolido por Justiniano, pois sua constituição (embora a questão seja controvertida) só fala de pluralidade de devedores. Em matéria de "pactum de non petendo", de confusão e de compensação, pelo contrário, não está provado possa o direito adquirido contra um dos credores ser utilisado contra os outros. Não há textos sốbre confusão e compensação, mas, sôbre "pactum de non petendo", o texto de Paulo, D., 2, 14, "De pactis", 27, pr. (citado à pág. 225) declara subsistente, em caso de pacto consentido por um dos credores, o direito de agir dos outros. Finalmente, quanto à interrupção da prescrição extintiva, ela se aplica às duas correalidades. (Vêr C., 8,39(40), "De duobus reis", 4(5), citado à p. 222).

Resta a questão da contribuição: se só um dos credores recebeu o pagamento, terão os outros recurso contra êle? se só um dos devedores pagou, terá recurso contra os outros? Existe, neste ponto, uma distinção bem conhecida: há ou não sociedade entre credores, dum lado e devedores do outro? Se há, se êles se acham ligados por laços de sociedade ou de indivisão, a ação oriunda de tais laços 
("pro socio", "familiae erciscundae", "communi dividundo") permitirá dividir entre todos os lucros e encargos.

D., 35, 2, "Ad leg. Falcid.”, 62, pr. - Ulpiano - "In lege Falcidia hoc esse servandum Julianus ait, ut si duo rei promittendi fuerint, vel duo rei stipulandi: si quidem socii sint, in ea re dividi inter eos debere obligationem, atque si singuli partem pecuniae stipulati essent, vel promisissent. Quod si societas inter eos nulla fuisset, in pendenti esse, in utrius bonis computari oporteat id quod debetur, vel ex cujus bonis detrahi"

Tradução: "Tratando-se de fixar a Falcídia nos bens dum testador, credor com outrém ou devedor solidário duma soma, é preciso, segundo Juliano, distinguir se o testador era sócio do outro; neste caso, deve a obrigação dividir-se entre os dois, como se cada um houvesse estipulado ou prometido separadamente essa soma. Se porém não havia sociedade, fica pendente a questão de saber em qual dos patrimônios dos dois credores deve ser incluída a soma, ou de qual dos patrimônios dos dois dévedores deve ela ser deduzida". Além disso, na correalidade passiva, o codevedor de quem se reclama o pagamento, oferecendo-o na totalidade, tem, como o fiador, o direito de exigir a cessão das ações do credor, afim de melhor assegurar seu recurso contra os demais devedores.

Os dois textos abaixo, o demonstram e permitem exigir a cessão mesmo não havendo sociedade.

D., 19, 2, “Locati", 47, Marcelo (citado à página 204).

C., 4, 65, 13 - "Si divisa conductio fuit, et in singulis pro partibus facta: alieno nomine conveniri vos non oportet. Si autem omnes qui conducebant, in solidum locatori sunt obligati: jus ei competens conveniendi quem velit, non debet auferri. Habetis sane vos facultatem locatori offerendi debitum; et ut transferantur in vos ea quae ob hanc conductionem ab iis quorum nomine inquietamini, obligata sunt, postulandi".

Tradução: "Se a coisa objeto do contrato de locação foi parcialmente cedida, de modo a caber uma parte a 
cada um, não podeis ser acionados uns pelos outros. Mas, se todos os locatários se obrigaram solidàriamente, não se pode privar o dono de seu direito de acionar o locatário que tiver escolhido. Tendes, entretanto, a faculdade de of erecer pagamento ao dono afim de poderdes exigir sejam executadas as obrigações pelas quais sois chamados a juízo e contraídas pelos outros, por ocasião do contrato de locação". Se não há sociedade alguma quer entre credores quer entre devedores, pcde existir mandato, quando o segundo credor é na realidade adjunto do primeiro, incluído no contrato afim de receber pagamento; o mesmo pode suceder em relação ao segundo devedor, incluído como fiador. No primeiro caso, o "adjectus solutionis causa" fica sujeito à "actio mandati directa"; no segundo, a caução obterá indenização mediante a "actio mandati contraria".

Resta, porém, uma última situação: pode não haver vínculo algum entre os codevedores ou os credores. Fal tará, porisso, qualquer forma de prestação de contas entre êles, extinta a obrigação? Parece difícil admití-lo; entretanto, a solução é certa, no tocante à solidariedade ativa; quanto à solidariedade passiva, porém, a única de alcance prático, nada nos impede admitir a possibilidade do devedor, pagando, obter, como o fiador, recurso contra os outros devedores, exigindo a cessão das ações do credor. Alguns autores, como Accarias, objetam contra esta solução, lembrando a falta de qualquer laço entre o devedor que paga e seus codevedores. Tal fato, porém, não constitui obstáculo pois também o fiador, pedindo a cessão das ações para recorrer contra seus co-fiadores nenhuma relação mantém com êles. Devemos, por outro lado, admitir que Ulpiano, citando Juliano, D., 35, 2, "Ad leg. Falcid.", 62, pr. (citado, p. 227), parece negar qualquer recurso, em falta de sociedade. Mas, o direito de requerer a cessão das ações é concedido indistintamente por Diocleciano, C., 8, 39(40), "De duobus reis", 1(2): "Creditor prohiberi non potest exigere debitum, cum sint duo rei promittendi ejusdem pecuniae a quo velit. Et ideo si probaveris te conventum in solidum exsolvisse: rector provinciae juvare te adversus 
eum cum quo communiter mutuam pecuniam accepisti, non cunctabitur".

Tradução: “Quando duas pessoas se obrigarem solidàriamente perante um credor, pela mesma soma, êste último não pode ser impedido de escolher o devedor do qual prefere exigir o pagamento. $\mathrm{E}$ porisso, se provares que executado, pagaste tôda a dívida, o presidente da província não hesitará em te ajudar contra quem recebeu em comum contigo a soma emprestada". Dernburg combina com esta constituição, Papiniano, D., 45, 2, 11 (citado à p. 208) e pensa que a solução de Diocleciano foi favorecida pela fórmula segundo a qual os devedores correais se constituiam fiadores simultâneos uns dos outros (p. 208).

\section{Obrigações "in solidum"}

$\mathrm{Na}$ obrigação "in solidum", também chamada solidariedade imperfeita, responsabilidade coletiva, os devedores se exoneram graças ao pagamento feito por um só; mas, a "litis contestatio" feita com um não exonera os demais, razão pela qual se admite haver não só pluralidade de vínculos como também pluralidade de obrigações.

I. Fontes das obrigações "in solidum" - A solidariedade simples pode ser ativa ou passiva, como a correalidade. Os textos nos apresentam sobretudo a obrigação "in solidum" a cargo de vários devedores. Quanto às suas fontes, pretendeu-se, considerando-a mera variedade de solìdariedade convencional, ser a obrigação "in solidum" a solidariedade dos contratos de bôa fé enquanto a correalidade seria a solidariedade dos contratos de direito estrito. A convenção de solidariedade originaria pelo menos (salvo cláusula expressa em contrário) obrigação correal, no caso de contrato de direito estrito e obrigação "in solidum" no de contrato de boa fé (vide, a p. 210 dêste estudo, a exposição e a crítica de tal doutrina, sustentada primeiro por Demangeat e depois por Hauriou). 
A doutrina mais acertada parece ser aquela explicando o fenômeno jurídico fora de qualquer idéia de convenşão. Quando um prejuízo é injustamente causado a alguém por várias pessoas, cada culpado deve repará-lo integralmente, pois a responsabilidade de cada um não deve ser diminuida pela dos outros. Mas, o pagamento feito por um exonera os demais, pois, pelo pagamento o prejuízo é reparado. A idéia, surgindo primeiro em matéria de delitos, era estranha ao antigo "jus civile": êste admitia a cumulação de ações delituais contra todos os autores do delito. Assim acontecia não só na "actio furti" como também na "Actio legis Aquiliae"

Textos. "Actio furti": C., 4, 8, "De cond. furt.", 1 "Praeses provinciae sciens furti quidem actione singulos quosque in solidum teneri, condictionis vero numorum furtim subtractorum electionem esse, actum demum si ab uno satisfactum fuerit, caeteros liberari: jure proferre sententiam curabit"

Tradução: “O presidente da província, que não o ignora, declarará em sua sentença, na ação de furto, a responsabilidade solidária de cada um, mas, quanto à ação condicional de repetição do dinheiro furtado, se, intentada contra um dos autores do furto, êste satisfizer à vítima, os outros autores se exoneram"

Actio legis Aquiliae - D., 9, 2, "Ad legem Aquilliam", 11, 2 - Ulpiano - "Sed si plures servum percusserint, utrum omnes, quasi occiderint teneantur videamus? Et si quidem apparet cujus ictu perierit, ille quasi occiderit tenetur: quod si non apparet, omnes quasi occiderint teneri Julianus ait; et si cum uno agatur, caeteri non liberantur: nam, ex lege Aquilia, quod alius praestitit, alium non relevat: cum sit poena"

Tradução: "Mas, se vários houvessem ferido o escravo, responderão todos, como se todos o houvessem morto? Sabendo-se de quem partiu o golpe mortal, responderá quem o tiver desferido; não sendo possivel saber, todos responderão pela morte do escravo, segundo Juliano; e condenado um, nem porisso se exoneram os demais; pois, de 
acôrdo com a lei Aquilia, o que um paga, não aproveita ao outro. Com efeito, esta lei é penal"

Mas, no Império, em consequência dum movimento desconhecido ainda de Labeão e talvez promovìdo por Sabino, o princípio das obrigações "in solidum" se aplicou, progressivamente, ao caso de várias pessoas obrigadas a reparar o prejuízo resultante de delito, por meio duma ação considerada reipersecutória, por exemplo a "actio quod metus causa", "actio de dolo", a "actio rationibus distrahendis" e talvez a "condictio furtiva".

Que o movimento fôsse ainda desconhecido de Labeão, parece resultar de Ulpiano, D., 43, 24, "Quod vi aut clam", 15,2 - "Si in sepulchro alieno terra congesta fuerit jussu meo, agendum esse quod vi aut clam mecum, Labeo scribit: ei si communi consilio plurium id factum sit, licere, vel cum uno, vel cum singulis experiri: opus enim quod a pluribus pro indiviso factum est, singulos in solidum obligare. Si tamen proprio quis eorum consilio hoc fecerit, cum omnibus esse agendum, scilicet insolidum. Itaque alter conventus alterum non liberabit: quinimo perceptio ab altero: superiore etenim casu alterius conventio alterum liberat. Praeterea sepulchri quoque violati agi potest".

Tradução: "Escreve Labeão: se por minha ordem se amontoou terra em lugar destinado à sepultura de alguém, poder-se-á propor contra mim o interdito "quod vi aut clam"; e se a obra se fêz por conselho unânime de vários, o interdito se poderá propor contra um dêles, ou contra cada qual em particular. Pois, a obra indivisa, feita por muitos, obriga cada um solidàriamente. Se todavia, alguns realizaram a obra por seu próprio alvitre, é necessário acionar todos, isto é, solidàriamente. Por conseguinte, acionando-se um apenas ou mesmo, obtendo-se a condenação apenas contra um, os outros não se exoneram; enquanto, no caso precedente, proposta a ação contra um, exoneram-se os outros. Pode-se, também, intentar no caso. a ação de violação de sepulcro" Neste texto, deixando de lado as obscuridades produzidas por interpolação ou cor- 
rupção, Ulpiano não encontra solução intermediária entre a cumulação, aplicada outrora a tôda as ações delituais e a exoneração por "litis contestatio" resultante da identidade de "res". São mesmo compreensíveis as incertezas da doutrina colocando entre as obrigações correais a pretexto de identidade de "res", certas relações, melhor subordinadas às obrigaçôes "in solidum"; tudo isto, antes de aparecerem as ações reipersecutórias e mistas, não cumulativas. As citações de Sabino, permitindo supor tenha sido êle o iniciador do movimento doutrinal, são as seguintes:

D., 27, 6, "Quod falso tut.", 8 - "Et ideo si nihil, aut non totum servatum sit, in reliquos non denegandum in "id quod deest, Sabinus scribit".

Tradução: "Porisso, diz Sabino: se o autor nada obteve ou não obteve integralmente seu crédito, dum dos tutores, conserva sua ação contra os outros".

D., 43, 16, "De vi", 1, 13 - "Quotiens verus procurator dejecerit, cum utrolibet eorum, id est, sive domino, sive procuratore, agi posse Sabinus ait, et alterius nomine alteri eximi: sic tamen, si ab altero eorum litis aestimatio fuerit praestita. Non enim excusatus est, qui jussu alicujus dejecit, non magis quam si jussu alicujus occidit. Cum autem falsus est procurator, cum ipso tantum procuratore, interdici debere: Sabini sententia vera est".

Tradução: "Quando o esbulho fôr praticado pelo verdadeiro procurador, Sabino considera possível o uso do interdito tanto contra o constituinte como contra o procurador, desonerando-se um pela condenação do outro, se a condenação tiver sido executada. Pois, quem esbulhou por ordem de outrem não é mais escusável do que quem tiver morto por ordem de outrem. Sendo porém falso o procurador, só contra êste pode ser dirigido o interdito: a opinião de Sabino é verdadeira".

D., h. t., 1, 14 - "Sed et si quod alius dejecit, ratum habuero, sunt qui putent secundum Sabinum et Cassium, qui ratihabitionem mandato comparant, me videri dejecisse, interdictoque isto teneri. Et hoc verum est: rectius enim dicitur, in maleficio ratihabitionem mandato comparari”. 
Tradução: "Se eu, todavia, tiver ratificado o esbulho praticado em meu nome, muitos jurisconsultos, comparando segundo Sabino e Cassio a ratificação ao mandato, consideram o esbulho como por mim mesmo praticado, admitindo fique eu sujeito ao interdito. Esta opinião é verdadeira: pois, em matéria de delito é justo comparar a ratificação ao mandato".

Éstes dois textos são citados por Dernburg, como exemplos da nova orientação em matéria de obrigações "in solidum", iniciada por Sabino. Eisele, pelo contrário, considera-os interpolados.

Sôbre "actio quod metus causa", D., 4, 2, "Quod metus causa gestum erit", 14, 15, Ulpiano - "Secundum haec, si plures metum adhibuerint, et unus fuerit conventus; siquidem sponte rem ante sententiam restituerit, omnes liberati sunt. Sed et si id non fecerit, sed ex sententia quadruplum restituerit, verius est, etiam sic perimi adversus caeteros metus causa actionem".

Tradução: "De acôrdo com êsses princípios, se a violência foi praticada por vários, tendo porém a ação sido proposta só contra um, se êste restitui voluntàriamente a coisa antes da sentença, todos os outros se exoneram. Porém, se não se executar voluntàriamente, pagando entretanto o quádruplo em virtude de sentença, é mais verdade extinguir-se também nesse caso a ação de coação contra os outros".

Dolo - D., 4, 3, "De dolo malo", 17, Ulpiano - "Si plures dolo fecerint, et unus restituerit, omnes liberantur. Quod si unus, quanti ea res est, praestiterit, puto adhuc caeteros liberari".

Tradução: "Sendo vários os autores do dolo, todos se exoneram pela restituição efetuada por um. Mas, se um dos autores, indenizar por perdas e danos, penso que tambèm os outros se exoneram".

Ação "rationibus distrahendis" - Trifonino-D., 26, 7, "De adm. tut.", 55, 1 - "Sed si ipsi tutores rem pupilli furati sunt, videamus, an ea actione, quae proponitur ex 
lege duodecim tabularum adversus tutorem in duplum, singuli in solidum teneantur? Et quamvis unus duplum praestiterit, nihilominus etiam alii teneantur: nam in aliis furibus ejusdem rei pluribus, non est propterea caeteris poenae deprecatio, quod ab uno jam exacta est. Sed tutores, propter admissam administrationem, non tam invito domino contrectare eam videntur, quam perfide ager: Nemo denique dicet, unum tutorem et duplum, hac actione praestare, et quasi specie condictionis, aut ipsam rem, aut ejus aestimationem".

Traducão: "Mas, se os próprios tutores tiverem furtado o pupilo, vejamos se cada tutor responde solidàriamente pela ação de restituição em dobro, proponivel contra o tutor, de acôrdo com a Lei das XII Tábuas? Emb̄ora um pague em dôbro, os outros são contudo responsáveis: pois, nos casos de vários autores do furto da mesma coïsa, não ficam êles isentos da pena, por um haver satisfeito ao autor. Mas, os tutores, devido à sua administração aceita, não parecem tanto subtrair a coisa, contra a vontade do dono, como agir pèrfidamente. Afinal, ninguém dirá que um tutor deve não só responder em dôbro como ainda, por uma espécie de "condictio" prestar ou a coisa ou seu valor"

"Condictio furtiva" - Esta ação, no caso de pluralidade de autores do furto, se extingue pela satisfação prestada por um dêles, C., 4, 8, "De cond. furt.", 1 (texto citado, pp. 230).

Eisele, segundo Girard, admite a existência de obrigação "in solidum" nos três casos de "metus", dolo e "actio rationibus distrahendis". Pelo contrário, e no mesmo sentido de Demangeat, Eisele interpreta a constituição como determinando, ainda antes de Justiniano, a extinção da ação pela "litis contestatio"

No Império, ainda, a idéia de obrigação "in solidum" se aplicou aos casos de dolo ou culpa de muitos, na execução de obrigação contratual ou quase contratual. Por exemplo: obrigação comum de vários tutores, sancionada 
pela "actio tutelae"; obrigação de custódia, no comodato e depósito, obrigação de executar um mandato.

Tutores: D., 26, 7, "De adm. tut.", 18,1 - Ulpiano — "Ex duobus tutoribus si cum altero actum fuerit, alter non liberabitur".

Tradução: "Havendo dois tutores, a ação proposta contra um não exonera os outros"

D., 27, 3, "De tut. et rat. distr.", 15 - Ulpiano - "Si ex duobus tutoribus cum altero quis transegisset, quamvis ob dolum communem, transactio nihil proderit alteri: nec immerito: cum unusquisque doli sui poenam sufferat. Quod si conventus alter praestitisset, proficiet id quod praestiti, ei qui conventus non est: licet enim doli ambo rei sint, tamen sufficit unum satisfacere: ut in duobus, quibus res commodata est, vel deposita, quibusque mandatum est"

Tradução: "Se, dentre dois tutores, o pupilo transigir com um, a transação em nada aproveitará ao outro, embora o dolo seja comum. Isto é justo: pois cada qual deve sofrer a pena do próprio dolo. Mas, se um dêles, sendo acionado, pagar, êste pagamento exonerará ao outro: pois, embora ambos respondam pelo dolo, basta entretanto o pagamento feito por um, como no caso de dois comoditários, depositários, mandatários"

Locatários e comoditários — Ulpiano - 13, 6, "Comod.", 5, 15 — "Si duobus vehiculum commodatum sit, vel locatum simul, Celsus filius scripsit libro sexto digestorum, quaeri posse utrum unusquisque eorum insolidum, an pro parte teneatur? Et ait duorum quidem insolidum dominium vel possessionem esse non potest: nec quemquam partis corporis dominum esse, sed totius corporis pro indiviso pro parte dominium habere: usum autem balnei quidem vel porticus vel campi uniuscujusque insolidum esse: neque enim minus me uti quod et alius uteretur. Verum in vehiculo commodato, vel locato, pro parte quidem effectu me usum habere: quia non omnia loca vehiculi teneam. Sed esse verius ait, et dolum et culpam et diligentiam et custodiam in totum me praestare debere: quare duo 
quodammodo rei habebuntur: etsi alter conventus praestiterit, liberabit alterum: et ambobus competit furti actio".

Tradução: "Se um veículo fôr comodado ou locado simultâneamente a dois, Celso filho escreveu no livro sexto do digesto que se pode perguntar se cada um dêles é responsável solidàriamente ou em parte? E não admite o domínio ou a posse por inteiro em favor de dois; assim, cada qual não é dono duma parte da coisa, mas tem o domínio parcial de tôda a coisa indivisa. Porém, o uso dum balneário, passeio ou campo cabe por inteiro a cada um: pois, eu não posso usar menos do que o outro. Posso porém usar em parte do veículo comodado ou locado, pois, não ocupo todos os lugares do veículo. Mas, afirma ser mais verdadeiro dever eu responder integralmente por dolo, culpa, falta de diligência e custódia. Haverá assim, de certo modo, dois devedores solidários. Se um dêles, acionado, pagar, o outro se exonerará; e a ambos compete a ação de furto".

Depositários: D., 16, 3, “Dep.”, 1, 43 - Ulpiano — "Si apud duos sit deposita res, adversus unumquemque eorum agi poterit: nec liberabitur alter, si cum altero agatur: non enim electione, sed solutione, liberantur. Proinde si ambo dolo fecerunt, et alter quod interest praestiterit, alter non convenietur, exemplo duorum tutorum. Quod si alter vel nihil vel minus facere potest, ad alium pervenietur. Idemque et si alter dolo non fecerit, et idcirco sit absolutus: nam ad alium pervenietur".

Tradução: "Se a coisa fôr depositada junto a dois depositários, pode-se agir contra cada um dêles; nem se exonerará um, se a ação fôr proposta contra o outro, pois, as partes se exoneram não pela escolha, mas pelo pagamento. Porisso, havendo dolo de ambos, se um indenizar ao autor por perdas e danos, o outro não será acionado, como acontece no caso de dois tutores. Mas, se um nada pode ou pode menos, executa-se o outro. $O$ mesmo, se não houver dolo de um, sendo porisso absolvido; pois, executar-se-á o outro". 
Mandatários: D., 11, 6, "Si mensor", 3, pr. - Ulpiano - "Si duobus mandavero, et ambo dolose fecerint, adversus singulos insolidum agi poterit: sed altero convento, si satisfecerit, in alterum actionem denegari oportebit".

Tradução: "Se eu tiver constituído dois mandatários, e ambos agirem com dolo, poderei agir contra cada um integralmente; mas, se o escolhido por mim pagar, deve-se negar ação contra o outro". Eisele considera todos os textos aqui citados sôbre "metus", dolo, ação "rationibus distrahendis", etc. como interpolados. Para êle orginàriamente as fontes estabeleciam em todos os casos correalidade não convencional, em virtude de identidade de causa da dívida. Existe, ainda, um caso de obrigação "in solidum", admitido pelo próprio Eisele; é o de várias pessoas mandando, iñdependentemente uma da outra, alguém fazer determinado empréstimo. Elas respondem, cada uma, pela totalidade do prejuízo.

D., 46, 1, "De fidejuss.", 52, 3. - Papiniano - "Plures ejusdem pecuniae credendae mandatores, si unus judicio eligatur, absolutione quoque secuta non liberantur: sed omnes liberantur pecunia soluta".

Tradução: "Sendo vários os mandantes da mesma soma, se um fôr chamado a juízo os outros não se exoneram mesmo em caso de absolvição: mas, todos se exoneram pelo pagamento".

Em todos êsses casos, pode-se reclamar, de cada obrigado, a reparação integral do prejuízo, pois, a culpa dos outros não deve diminuir sua responsabilidade. Mas, prestada a reparação por um, nada mais podemos exigir aos outros, pois o prejuízo só se repara uma vez:

II. Efeitos das obrigações "in solidum" - A própria idéia fundamental da obrigação "in solidum", da solidariedade imperfeita ou da responsabilidade coletiva leva à seguinte conclusão: se o pagamento efetuado por um dos devedores exonera os outros, o mesmo não acontece com a "litis contestatio" feita com um dos devedores, e isto já antes de Justiniano. Ulpiano, por exemplo, D., 16, 3, “Dep.", 
1, 43 (texto citado, p. 236) diz: "Non enin electione, sed solutione liberantur", "os devedores ("in solidum") não se exoneram pela "1. c." feita com um mas pelo pagamento". Além disso, a novação e a aceptilação, quando feitas com um ou em favor dum dos devedores, não devem lògicamente aproveitar aos outros. Neste sentido, Girardin invoca UIpiano, D., 27, 3, "De tut.", 15 (citado, p. 235), aplicando o mesmo princípio contido nesse texto ao juramento e, inversamente, à interrupção da prescrição ( $O$ princípio é o do efeito puramente pessoal dos atos mencionados).

Enfim, a responsabilidade "in solidum" é compatível com o benefício de divisão, reconhecido talvez a todos os devedores, em todo caso, com certeza, aos depositários e tutores, responsáveis por culpa, mas não por dolo.

Textos: Depositários - D., 16, 3, “Dep.", 22 - Marcelo - "Si duo heredes rem apud defunctum depositam interverterint, quodam utique casu in partes tenebunt:ir: nam si diviserint decem millia, quae apud defunctum deposita fuerant et quina millia abstulerint, et uterque solvendo est, in partes obstricti erunt: nec enim amplius actoris interest. Quod si lancem conflaverint, aut conflari ab aliquo passi fuerint, aliave quae species dolo eorum interversa fuerit, insolidum conveniri poterunt, ac si ipsi servandam suscepissent: nam certe verum est insolidum quemque dolo fecisse: et nisi pro solido res non potest restitui. Nec tamen absurde sentiet, qui hoc putaverit, plane nisi integrae rei restitutione eum, cum quo actum fuerit, liberari non posse, condemnandum tamen, si res non restituetur, pro qua parte heres exstitit"

Tradução: "Se dois herdeiros furtarem uma coisa depositada com o defunto, responderão, em certos casos, cada um em parte: pois, se dividirem dez mil, importância depositada com o defunto, e furtarem cinco mil, sendo ambos capazes de pagar, cada um responderá por parte, pois, o autor não tem interêsse maior. Mas, se fundirem um prato, ou o deixarem fundir por outrem, ou se qualquer outra coisa por seu dolo fôr subtraída, poderão ser chamados 
a responder cada um pela totalidade da coisa, como se êles mesmos a houvessem recebido em depósito. Pois, é fora de dúvida haver, cada um, agido com dolo integral: e a coisa não pode ser restituída se não por inteiro. Todavia, não será absurdo pensar assim: embora, sem dúvida, não se exonere o réu senão pela restituição integral da coisa, deve ser condenado, em falta de restituição, de acôrdo com sua parte na herança"

Tutores: D., 27, 3, "De tut.", 1, 11 - Ulpiano - "Et si quidem omnes simul gesserunt tutelam et omnes solvendo sunt, aequissimum erit dividi actionem inter eos pro portionibus virilibus exemplo fidejussorum" 12 . Sed et si non omnes solvendo sint, inter eos qui solvendo sunt, dividitur actio. Sed prout quisque solvendo est, poterunt conveniri".

Tradução - D., 27, 3, 1, 11 - "E por certo, se todos exerceram simultâneamente a tutela e são todos solventes, será da maior equidade dividir entre êles a ação em partes iguais, a exemplo dos fiadores".

12. - "Mas, se nem todos forem solventes, a ação se divide entre os solventes: em tal caso, porém, cada um só responderá na medida de suas fôrças"

$O$ devedor, pagando integralmente, pode recorrer contra seus codevedores, obtendo, do credor, cessão das ações dêste contra êles, também em caso de culpa e não no de dolo.

D., 27, 3, "De tut.", 1, 13 - "Et si forte quis ex facto alterius tutoris condemnatus praestiterit vel ex communi gestu nec ei mandatae sunt actiones, constitutum est a divo Pio et ab imperatore nostro et divo patre ejus utilem actionem tutori adversus contutorem dandam"

14. "Plane si ex dolo communi conventus praestiterit tutor, neque mandandae sunt actiones neque utilis competit, quia proprii delicti poenam subit: quae res indignum eum fecit, ut a caeteris quid consequatur doli participibus: nec enim ulla societas maleficiorum vel communicatio justa damni ex maleficio est". 
Tradução: D., 27, 3, "De tut.", 1, 13 - "E se por acaso, um dos tutores, condenado por fato do outro, ou por gestão comum, pagar, não se lhe transferindo as ações, foi constituido pelo imperador Pio e pelo nosso imperador e seu pai, caber ao tutor uma ação útil contra o co-tutor".

D., h. t., 1, 14 - Mas, se o tutor, acionado em consequência de dolo praticado junto com outros tutores, pagar, nem terá direito de exigir a transferência das ações, nem de obter uma ação útil: a gestão desonesta, tornou-o indigno de obter qualquer coisa dos outros, participantes do dolo. Pois, nenhuma sociedade de crimes é admitida, assim como não se admite qualquer comunicação justa do dano oriundo de crime". 